\title{
Botrytis Blossom Blight of Southern Blueberries: Cultivar Susceptibility and Effect of Chemical Treatments
}

\author{
Barbara J. Smith, USDA-ARS, Small Fruit Research Station, P.O. Box 287, Poplarville, MS 39470
}

\begin{abstract}
Smith, B. J. 1998. Botrytis blossom blight of southern blueberries: Cultivar susceptibility and effect of chemical treatments. Plant Dis. 82:924-927.

The susceptibility of blueberry flowers at each developmental stage was evaluated by inoculating potted blueberry bushes of the rabbiteye cultivars Climax, Premier, and Tifblue, and the southern highbush cultivars Gulfcoast and Cooper, during bloom with a conidial suspension of Botrytis cinerea and incubating in a dew chamber for 2 days at $20^{\circ} \mathrm{C}$ and $100 \%$ relative humidity. Flower stage was rated at the beginning of each study and at 2 and 4 weeks after inoculation. The efficacy of five fungicides (benomyl, captan, cyprodinil, cyprodinil + CGA173506, and propiconazole) and a surfactant for control of Botrytis blossom blight was evaluated by inoculating Climax and Gulfcoast plants 2 days before or 2 days after treatment with each fungicide. The effect of chemicals used during bloom on the severity of Botrytis blossom blight was evaluated by treating Tifblue and Cooper plants with gibberellic acid, surfactant, and fungicide combinations 1 day prior to inoculation. Botrytis disease symptoms were scored 2 and 4 weeks after inoculation on a visual scale of 0 to 7 . Flower susceptibility increased as flower stage at inoculation increased. Tifblue flowers at or near full bloom (stages 5 and 6 ) at the time of inoculation were very susceptible to Botrytis blossom blight. Flowers treated with benomyl, cyprodinil, and cyprodinil + CGA173506 2 days after inoculation had lower Botrytis severity scores than inoculated flowers not treated with fungicides. Flowers treated with gibberellic acid 1 day prior to inoculation had lower Botrytis scores 2 and 4 weeks later than untreated flowers, while flowers treated with a nonionic surfactant received the same Botrytis severity scores as untreated flowers.
\end{abstract}

Blueberries are a major North American fruit crop, and their production is steadily increasing, particularly in the southeastern United States, where the area planted to rabbiteye blueberries (Vaccinium ashei Reade) more than doubled between 1982 and 1992 (14). One of the main causes of crop loss of rabbiteye blueberries in the Gulf South in recent years has been death or injury of flowers due to late spring freezes. Southern highbush blueberry cultivars (hybrids between northern highbush blueberry [V. corymbosum L.] and various native southern Vaccinium spp.) offer some protection against late spring freeze injury because they flower later than most rabbiteye cultivars (6). Despite the later flowering of southern highbush cultivars, their fruit ripen earlier than rabbiteye cultivars. The area planted with southern highbush cultivars in the deep south is increasing; however, almost nothing is known about the susceptibility of these cultivars to diseases $(6,12,16)$.

Corresponding author: Barbara J. Smith E-mail: bjsmith@ag.gov

Accepted for publication 13 May 1998.

Publication no. D-1998-0617-01R

This article is in the public domain and not copyrightable. It may be freely reprinted with customary crediting of the source. The American Phytopathological Society, 1998.
Botrytis blossom blight (caused by the fungus Botrytis cinerea Pers.:Fr.) sometimes causes severe crop loss of rabbiteye blueberries but usually is unimportant on highbush blueberry $(3,5,13,20)$. Its effect on southern highbush blueberry cultivars is unknown. On rabbiteye blueberry, the fungus attacks blossoms, tender green twigs, and leaves in early spring, causing symptoms that are often mistaken for freeze injury. Infected flowers and twigs quickly turn brown or black and die. The fungus produces abundant gray masses of conidia that can quickly spread throughout the field. High humidity (>95\%) and cool temperatures $\left(15\right.$ to $\left.20^{\circ} \mathrm{C}\right)$ are ideal for Botrytis infection. Often the fungus will advance from infected flower clusters into the stem, girdling it and killing all flowers above the infection point. Botrytis is an aggressive saprophyte, which also invades tissue injured in a spring frost (1). The same fungus also causes Botrytis fruit rot, but in the southeastern United States, most losses on rabbiteye blueberry are due to blossom blight rather than fruit rot.

Botrytis blossom blight has been especially severe in Georgia on Tifblue when cool, rainy weather occurs during bloom (10). Due to the similarity between Botrytis blossom blight and freeze injury $(1,3,10,13,20)$, some losses attributed to freeze injury in the past may have actually been caused by Botrytis blossom blight. Fungicides recommended during bloom for disease control on southern blueberries include benomyl and captan for Botrytis blossom blight and triforine and benomyl for mummy berry control $(4,13)$; however, fungicidal control of Botrytis blossom blight often has been unsatisfactory. The interaction between gibberellic acid-surfactant treatments (sometimes applied during bloom to improve fruit set caused by poor pollination or slight freeze injury [11]), fungicides, and Botrytis blossom blight on rabbiteye and southern highbush cultivars has not been investigated previously. The objectives of this study were to determine (i) the susceptibility of blueberry flowers at each developmental stage to Botrytis blossom blight, (ii) the relative susceptibility of rabbiteye and southern highbush blueberry cultivars, (iii) the efficacy of several fungicides for control of this disease, and (iv) the effect of gibberellic acid and surfactants on Botrytis blossom blight severity.

\section{MATERIALS AND METHODS}

Plant maintenance. Two- and threeyear-old plants of the southern highbush cultivars Cooper and Gulfcoast, and rabbiteye cultivars Climax, Premier, and Tifblue, were grown in 3-liter pots containing a mixture of coarsely ground pine bark and sand $(1: 1, \mathrm{vol} / \mathrm{vol})$. Plants were spaced 30 $\mathrm{cm}$ apart on black fabric mulch placed on the ground, watered as needed via overhead irrigation, and subjected to naturally occurring temperature and rain conditions until mid-February. At the beginning of each study, plants of each cultivar were selected for uniformity of size and flower bud development and randomly assigned to treatment groups. All flower buds (up to 50 ) on each plant were tagged and rated for flower stage development on a scale of $1=$ dormant bud to $7=$ flower whose corolla has dropped (18). Any young berries that developed as the study progressed were given a flower stage rating of 8 . Subsequent development of each bud was rated 2 and 4 weeks after inoculation.

Inoculum production. $B$. cinerea was isolated from a Tifblue blueberry plant grown in south Georgia by harvesting conidia with a sterile needle from diseased flowers and spreading conidia over the surface of potato dextrose agar (PDA) acidified with $1 \mathrm{ml}$ of lactic acid per liter. The isolate was maintained on PDA until needed. Fungal inoculum was prepared from 10- to 16-day-old cultures grown at approximately $22^{\circ} \mathrm{C}$. A conidial suspension 
was prepared by flooding plates with sterilized distilled water and dislodging conidia by stirring with a glass rod. Conidia were counted using a hemacytometer, and the spore concentration was adjusted to 2.5 $\times 10^{5}$ conidia $\mathrm{ml}^{-1}$ unless noted otherwise. Tween $20(0.04 \%)$ was added to the suspension prior to inoculation.

Buds and flowers on each plant were inoculated by using a hand pump sprayer to mist each plant with the conidial suspension to the point of runoff. Control plants were sprayed with sterile distilled water containing Tween 20 (0.04\%). Plants were then incubated for 2 days in a dark dew chamber (Percival I-60DL, Boone, Iowa) at $20^{\circ} \mathrm{C}$ and $100 \%$ relative humidity (RH). For the remainder of the study, plants were maintained in an unheated shade house on benches $2 \mathrm{~m}$ from a mist system (5 $\mathrm{s}$ of mist every $5 \mathrm{~min}$ for $16 \mathrm{~h}$ per day).

Disease assessment and data analysis. Two and four weeks after inoculation, flowers on each plant were rated for disease development. Botrytis symptoms were scored on a visual scale of $0=$ no visible symptoms, $1=$ small red spots on corolla, $2=$ one to four water-soaked lesions on corollas of flower cluster, $3=$ corollas of all flowers in a cluster brown, ovaries green and undamaged, $4=$ corollas brown and ovaries of young developing berries damaged, $5=$ all flowers or berries within a cluster dead, $6=$ all flowers or berries within a cluster dead and covered with spores, 7 = lesion extends from dead cluster into stem. Periodically, lesions from inoculated flowers were plated on acidified PDA to confirm the presence of the pathogen. Each study was designed as a randomized complete block, with individual plants being an experimental unit. Data were subjected to analysis of variance by PROC GLM with PC/SAS software (SAS Institute, Cary, NC). Means were separated by least significant difference $(P=0.05)$.

Cultivar and flower susceptibility. Fourteen potted plants of Tifblue and Premier and eight of Climax and Gulfcoast with flowers at various stages of development were selected for uniformity of size and flower bud development. Half the plants of each cultivars were randomly chosen and inoculated with $B$. cinerea. The remaining plants were sprayed with distilled water and served as uninoculated controls.

Comparison of two fungicides applied preinoculation. The effect of benomyl and propiconazole applications before infection was evaluated on two rabbiteye cultivars. Seven single-plant replicates of Tifblue and Premier received the following treatments: benomyl, propiconazole, or no fungicide applied 1 day prior to inoculation with $B$. cinerea as previously described, or no fungicide application and no inoculum other than natural inoculum in the house or on the plant. Only flower buds at stage 4 to 7 at inoculation were included in the data analysis.
Comparison of five fungicides applied pre- and postinoculation. A rabbiteye cultivar, Climax, and a southern highbush cultivar, Gulfcoast, were used to compare the pre- and postinfection applications of four systemic fungicides and a contact fungicide. Climax and Gulfcoast plants were inoculated with $B$. cinerea either 2 days before or 2 days after treatment with five fungicides, benomyl (Benlate 50WP, 1.49 g/liter, E.I. duPont de Nemours, Wilmington, DE), propiconazole (Orbit 3.6E, $0.58 \mathrm{ml} /$ liter, Ciba Crop Protection, Greensboro, NC [19]), captan (Captan 50WP, 7.5 g/liter, MicroFlo, Lakeland, FL), cyprodinil (CGA219417 75W, 0.99 g/liter, Ciba Crop Protection, Greensboro, NC [9]), and a combination of cyprodinil (CGA219417 $75 \mathrm{~W}, 0.772 \mathrm{~g} /$ liter) and a substituted benzdioxal-carbonitril fungicide (CGA173507 50W, 0.772 g/liter, Ciba Crop Protection). Benomyl and propiconazole were evaluated with and without a nonionic organosilicone surfactant (Silwet L-77, $0.25 \mathrm{ml} /$ liter, OSi Specialties, Inc., Tarrytown, NY). Controls included uninoculated plants (misted with distilled water) and inoculated plants not treated with fungicides. Each treatment was replicated four or five times for Climax and four times for Gulfcoast. Each replication

Table 1. Average blossom blight severity score and flower stage rating of four blueberry cultivars 2 and 4 weeks postinoculation with Botrytis cinerea

\begin{tabular}{|c|c|c|c|c|c|}
\hline \multirow[b]{2}{*}{ Main effect } & \multirow[b]{2}{*}{ Treatment } & \multicolumn{2}{|c|}{ Disease severity score ${ }^{w}$} & \multicolumn{2}{|c|}{ Flower stage $^{x}$} \\
\hline & & 2 weeks & 4 weeks & 2 weeks & 4 weeks \\
\hline \multirow[t]{4}{*}{ Cultivar } & Gulfcoast & $0.82 a^{y}$ & $1.81 \mathrm{a}$ & 6.6 & 7.5 \\
\hline & Climax & $0.60 \mathrm{bc}$ & $1.15 \mathrm{~b}$ & 6.2 & 7.3 \\
\hline & Premier & $0.53 \mathrm{c}$ & $1.33 \mathrm{~b}$ & 5.2 & 6.5 \\
\hline & Tifblue & $0.99 \mathrm{a}$ & $1.81 \mathrm{a}$ & 4.6 & 5.7 \\
\hline \multirow[t]{7}{*}{ Flower stage ${ }^{\mathrm{z}}$} & 1 & $0.00 \mathrm{c}$ & $0.22 \mathrm{c}$ & 2.2 & 4.0 \\
\hline & 2 & $0.03 \mathrm{c}$ & $0.38 \mathrm{c}$ & 4.1 & 5.8 \\
\hline & 3 & $0.27 \mathrm{c}$ & $1.29 \mathrm{bc}$ & 5.2 & 6.6 \\
\hline & 4 & $0.79 b c$ & $1.86 \mathrm{bc}$ & 6.0 & 7.0 \\
\hline & 5 & $1.80 \mathrm{ab}$ & $2.49 \mathrm{ab}$ & 6.6 & 7.2 \\
\hline & 6 & $1.41 \mathrm{ab}$ & $2.43 \mathrm{ab}$ & 7.0 & 7.5 \\
\hline & 7 & $2.25 \mathrm{a}$ & $4.00 \mathrm{a}$ & 7.4 & 7.6 \\
\hline
\end{tabular}

${ }^{\mathrm{w}}$ On scale of $0=$ no visible symptoms to $7=$ flower cluster dead with lesion extending into stem.

${ }^{x}$ On scale of 1 to 7 (18). Stage 8 represents young berries.

${ }^{y}$ Numbers followed by the same letter within main effect within columns are not significantly different. LSD, $P=0.05$.

${ }^{\mathrm{z}}$ Flower stage at inoculation.

Table 2. Average blossom blight severity score of four blueberry cultivars 4 weeks postinoculation with Botrytis cinerea

\begin{tabular}{lcccc}
\hline & \multicolumn{4}{c}{ Disease severity score } \\
\cline { 2 - 5 } Flower stage $^{\mathbf{w}}$ & Tifblue & Premier & Climax $^{\mathrm{x}}$ & Gulfcoast \\
\cline { 2 - 5 } 1 & $0.0 \mathrm{~d}^{\mathrm{y}}$ & $0.5 \mathrm{~b}$ & $* \mathrm{z}$ & $*$ \\
2 & $0.2 \mathrm{~d}$ & $0.6 \mathrm{~b}$ & $0.2 \mathrm{~d}$ & $2.5 \mathrm{a}$ \\
3 & $2.0 \mathrm{c}$ & $1.2 \mathrm{~b}$ & $0.7 \mathrm{~cd}$ & $1.6 \mathrm{a}$ \\
4 & $3.1 \mathrm{c}$ & $2.5 \mathrm{a}$ & $0.7 \mathrm{~cd}$ & $1.7 \mathrm{a}$ \\
5 & $4.8 \mathrm{~b}$ & $3.1 \mathrm{a}$ & $1.6 \mathrm{bc}$ & $1.7 \mathrm{a}$ \\
6 & $7.0 \mathrm{a}$ & $*$ & $2.2 \mathrm{ab}$ & $1.5 \mathrm{a}$ \\
7 & $7.0 \mathrm{a}$ & $*$ & $2.8 \mathrm{a}$ & $3.4 \mathrm{a}$ \\
Number of flowers & 335 & 360 & 314 & 110 \\
\hline
\end{tabular}

${ }^{\mathrm{w}}$ At inoculation, rated on scale of 1 to 7 (18).

${ }^{x}$ On scale of $0=$ no visible symptoms to $7=$ flower cluster dead with lesion extending into stem.

y Numbers followed by the same letter within columns are not significantly different. LSD. $P=0.05$.

${ }^{\mathrm{z}}$ No flowers at this stage at inoculation. was inoculated on a different date. Only in at stage 4 to 7 at inoculation averaged 22 buds per plant, and Gulfcoast .

study. The effect of chemicals used during highbush cultivar, Cooper. Up to 50 flow(i) ml/liter, Abbott Laboratories, North Chicago, liter), (iii) gibberellic acid + surfactant, and each plant was sprayed with one of two treatments: propiconazole (Orbit, replications of each cultivar were inoculated 1 . Two replications of each treatment on each

\section{RESULTS} When averaged over flower stages, all cultivars had low Botrytis severity scores stage. The plants were sprayed with one of IL), (ii) surfactant only (Silwet L-77, 0.24 
Table 3. Influence of fungicide treatments applied 1 day before inoculation with Botrytis cinerea on the severity of Botrytis blossom blight 2 and 4 weeks postinoculation on the rabbiteye blueberry cultivars Premier and Tifblue

\begin{tabular}{|c|c|c|c|c|c|c|}
\hline \multirow[b]{2}{*}{ Main effect } & \multirow[b]{2}{*}{ Treatment } & \multicolumn{2}{|c|}{ Disease severity score ${ }^{w}$} & \multicolumn{2}{|c|}{ Flower stage $^{x}$} & \multirow[b]{2}{*}{ Buds/bush ${ }^{y}$} \\
\hline & & 2 weeks & 4 weeks & 2 weeks & 4 weeks & \\
\hline \multirow[t]{3}{*}{ Cultivar } & Premier & $2.26 \mathrm{a}^{\mathrm{z}}$ & $3.04 \mathrm{a}$ & 6.01 & 6.71 & 18 \\
\hline & Tifblue & $0.82 \mathrm{~b}$ & $2.47 \mathrm{~b}$ & 6.05 & 6.81 & 14 \\
\hline & LSD & 0.33 & 0.41 & NS & NS & \\
\hline \multirow[t]{5}{*}{ Fungicide } & Benomyl & $1.43 \mathrm{bc}$ & 2.55 & 6.02 & $6.89 \mathrm{a}$ & 16 \\
\hline & Propiconazole & $2.02 \mathrm{a}$ & 2.97 & 6.03 & $6.74 \mathrm{ab}$ & 16 \\
\hline & None & $1.79 \mathrm{ab}$ & 3.09 & 5.95 & $6.60 \mathrm{~b}$ & 17 \\
\hline & Not inoculated & $1.25 \mathrm{c}$ & 2.54 & 6.10 & $6.79 \mathrm{ab}$ & 16 \\
\hline & LSD & 0.46 & NS & NS & 0.20 & \\
\hline
\end{tabular}

${ }^{\mathrm{w}}$ On scale of $0=$ no visible symptoms to $7=$ flower cluster dead with lesion extending into stem.

${ }^{x}$ On scale of 1 to 7 (18).

y Only flowers at stage 4 to 7 at inoculation were included in data analysis.

z Numbers followed by the same letter within columns within main effect are not significantly different. LSD, $P=0.05$.

Table 4. Influence of fungicide treatments applied 2 days before or 2 days after inoculation with Botrytis cinerea on the severity of Botrytis blossom blight 2 and 4 weeks postinoculation on the blueberry cultivars Climax and Gulfcoast

\begin{tabular}{|c|c|c|c|c|c|c|}
\hline \multirow[b]{2}{*}{ Fungicide } & \multirow{2}{*}{$\begin{array}{l}\text { Application } \\
\text { time }\end{array}$} & \multicolumn{2}{|c|}{ Disease severity scorew $^{w}$} & \multicolumn{2}{|c|}{ Flower stage $x$} & \multirow[b]{2}{*}{ Buds/bush ${ }^{\mathrm{y}}$} \\
\hline & & 2 weeks & 4 weeks & 2 weeks & 4 weeks & \\
\hline Benomyl & Before & $0.85 \mathrm{bc}^{\mathrm{z}}$ & $1.55 \mathrm{bc}$ & 7.0 & 7.5 & 17 \\
\hline Benomyl & After & $0.44 \mathrm{c}$ & $1.17 \mathrm{bcd}$ & 6.8 & 7.7 & 19 \\
\hline Captan & Before & $0.92 \mathrm{bc}$ & $1.30 \mathrm{bcd}$ & 6.8 & 7.5 & 20 \\
\hline Captan & After & $0.79 \mathrm{bc}$ & $1.35 \mathrm{bcd}$ & 6.5 & 7.5 & 21 \\
\hline Cyprodinil & Before & $0.77 \mathrm{bc}$ & $1.27 \mathrm{bcd}$ & 6.9 & 7.8 & 17 \\
\hline Cyprodinil & After & $0.41 \mathrm{c}$ & $0.69 \mathrm{~d}$ & 6.7 & 7.5 & 18 \\
\hline $\begin{array}{l}\text { Cyprodinil } \\
\text { +CGA173506 }\end{array}$ & Before & $1.14 \mathrm{~b}$ & $1.82 \mathrm{~b}$ & 6.8 & 7.5 & 17 \\
\hline $\begin{array}{l}\text { Cyprodinil } \\
\text { +CGA173506 }\end{array}$ & After & $0.43 \mathrm{c}$ & $0.85 \mathrm{~cd}$ & 6.9 & 7.7 & 17 \\
\hline Propiconazole & Before & $1.83 \mathrm{a}$ & $2.80 \mathrm{a}$ & 6.8 & 7.4 & 20 \\
\hline Propiconazole & After & $0.60 \mathrm{bc}$ & $1.28 \mathrm{bcd}$ & 6.8 & 7.6 & 17 \\
\hline \multicolumn{2}{|c|}{ Inoculated, no fungicide } & $1.21 \mathrm{ab}$ & $1.83 \mathrm{~b}$ & 6.8 & 7.6 & 19 \\
\hline \multicolumn{2}{|c|}{ Not inoculated } & $0.41 \mathrm{c}$ & $0.93 \mathrm{~cd}$ & 6.6 & 7.6 & 19 \\
\hline \multicolumn{2}{|l|}{ LSD } & 0.64 & 0.81 & 0.3 & 0.3 & \\
\hline
\end{tabular}

${ }^{\mathrm{w}}$ On scale of $0=$ no visible symptoms to $7=$ flower cluster dead with lesion extending into stem.

${ }^{x}$ On scale of 1 to 7 (18). Stage 8 represents young berries.

y Only flowers at stages 4 to 7 at inoculation were included in data analysis.

${ }^{\mathrm{z}}$ Numbers followed by the same letter within a column are not significantly different. LSD, $P=0.05$.

(Table 1); however, 4 weeks after inoculation, Tifblue and Gulfcoast had higher blossom blight scores than Premier and Climax. When averaged over cultivars, susceptibility increased at later flower stages. Four weeks after inoculation, buds inoculated at stage 1 through stage 3 developed little Botrytis blossom blight, while flowers inoculated at stages 5 to 7 developed more severe symptoms. When the interaction between flower stage at the time of inoculation and cultivar susceptibility is compared (Table 2), the extreme susceptibility of Tifblue at stage 5 and 6 is apparent. All Tifblue flowers that were at or near full bloom (stages 5, 6, and 7 ) at the time of inoculation with $B$. cinerea were killed within 4 weeks of inoculation. The flowers of Climax and Premier were more susceptible at stages 6 and 7, and at stages 4 and 5, respectively, than at earlier flower stages. Flower stage at inoculation did not affect the susceptibility of the southern highbush cultivar Gulfcoast. Most Climax, Premier, and Gulfcoast flowers were damaged, but not killed, regardless of flower stage at time of inoculation.
Comparison of two fungicides applied preinoculation. Two weeks after inoculation with $B$. cinerea, Premier flowers had higher Botrytis severity scores than Tifblue flowers (Table 3). Plants treated with propiconazole 1 day before inoculation had higher Botrytis severity scores than plants treated with benomyl or the uninoculated control plants. There was not a significant cultivar by fungicide treatment interaction.

Comparison of five fungicides applied pre- and postinoculation. Two weeks after inoculation with $B$. cinerea, the average Botrytis severity score of Climax flowers was higher $(0.97)$ than that of Gulfcoast flowers (0.70); however, by 4 weeks after inoculation, there was no difference in the severity scores of the two cultivars (1.52 and 1.43, respectively). There were no significant differences in the Botrytis severity scores of the plants treated with a fungicide and a surfactant and plants treated with the same fungicide and no surfactant; between fungicide treatment and cultivar; or between time of fungicide application and cultivar. There was a significant interaction between time of application and fungicide treatment (Table 4). Two weeks after inoculation, plants treated with propiconazole 2 days prior to inoculation had higher Botrytis severity scores than plants receiving all other treatments except those which received no fungicide treatment. Plants treated with benomyl, cyprodinil, and cyprodinil + CGA173506 2 days after inoculation had Botrytis severity scores significantly less than those of the inoculated untreated plants.

Flowers not killed by Botrytis blossom blight were allowed to develop fruit. Ripe berries were harvested from all plants, incubated in the laboratory for 5 days (17), and rated for fruit rot severity. Very few berries developed Botrytis fruit rot, and there were no significant differences among cultivars or fungicide treatments between inoculated and control plants in the percentage of berries with Botrytis fruit rot (data not shown).

Fungicide, gibberellic acid, surfactant study. There was no difference in Botrytis severity between inoculated and uninoculated plants; therefore the data from all six replications were combined within each cultivar. Four weeks after inoculation, the rabbiteye cultivar, Tifblue, had higher disease scores than the southern highbush cultivar, Cooper (Table 5). There were no differences in the disease severity scores of plants treated with surfactant and plants not treated with surfactant; however, those plants treated with gibberellic acid had lower Botrytis scores than plants not treated with gibberellic acid. Plants treated with the fungicide propiconazole received disease scores as high as those of plants not treated with a fungicide.

\section{DISCUSSION}

The low Botrytis severity scores of the three rabbiteye cultivars are supported by field observations in the southeastern United States, where in most years very little Botrytis blight has been reported. In areas such as southern Georgia and northern Florida, where Botrytis blight is considered a problem $(1,2,7,8)$, the rabbiteye cultivar Tifblue is usually the major cultivar. The increased susceptibility of flowers of all cultivars (except Gulfcoast) as bud stage progressed, combined with the extreme susceptibility of Tifblue flowers at stages 5 and 6, probably explains the severe occurrences of this disease that have occasionally been reported. Weather conditions conductive to Botrytis blight occurring at or near full bloom could result in severe Botrytis blight, particularly if these conditions occur following frost injury to the blooms. Pelletier and Hilborn (15) reported that blossoms of lowbush blueberry ( $V$. angustifolium Aiton) are more susceptible to Botrytis blight than are dormant buds. Blossoms required 3 or 4 days of high humidity for infection to occur, whereas dormant buds required 6 to 9 days of high humidity. 
Table 5. Influence of gibberellic acid, surfactant, and fungicide applications 1 day prior to inoculation with Botrytis cinerea on Botrytis blossom blight severity 0, 2, or 4 weeks postinoculation on Tifblue (rabbiteye) and Cooper (southern highbush) blueberries

\begin{tabular}{|c|c|c|c|c|c|c|c|}
\hline \multirow[b]{2}{*}{ Main effect } & \multirow[b]{2}{*}{ Treatment } & \multicolumn{2}{|c|}{ Disease severity score $^{\mathrm{x}}$} & \multicolumn{3}{|c|}{ Flower stage $^{\mathrm{y}}$} & \multirow[b]{2}{*}{ Buds/bush $^{\mathbf{z}}$} \\
\hline & & 2 weeks & 4 weeks & 0 weeks & 2 weeks & 4 weeks & \\
\hline Inoculated & $\begin{array}{l}\text { B. cinerea } \\
\text { None } \\
\operatorname{LSD}(P=0.05)\end{array}$ & $\begin{array}{l}0.89 \\
0.52 \\
\text { NS }\end{array}$ & $\begin{array}{l}1.72 \\
1.18 \\
\text { NS }\end{array}$ & $\begin{array}{l}5.7 \\
5.6 \\
\text { NS }\end{array}$ & $\begin{array}{l}7.0 \\
7.0 \\
\text { NS }\end{array}$ & $\begin{array}{l}7.7 \\
7.7 \\
\text { NS }\end{array}$ & $\begin{array}{l}4 \\
5\end{array}$ \\
\hline Cultivar & $\begin{array}{l}\text { Tifblue } \\
\text { Cooper } \\
\text { LSD }(P=0.05)\end{array}$ & $\begin{array}{l}1.00 \\
0.54 \\
\mathrm{NS}\end{array}$ & $\begin{array}{l}1.95 \\
1.13 \\
0.70\end{array}$ & $\begin{array}{l}5.8 \\
5.6 \\
\text { NS }\end{array}$ & $\begin{array}{l}6.9 \\
7.1 \\
0.1\end{array}$ & $\begin{array}{l}7.4 \\
8.0 \\
0.1\end{array}$ & $\begin{array}{l}5 \\
4 \\
1\end{array}$ \\
\hline Gibberellic acid & $\begin{array}{l}\text { ProGibb } \\
\text { None } \\
\text { LSD }(P=0.05)\end{array}$ & $\begin{array}{l}0.36 \\
1.01 \\
0.58\end{array}$ & $\begin{array}{l}0.84 \\
1.94 \\
0.72\end{array}$ & $\begin{array}{l}5.5 \\
5.8 \\
0.2\end{array}$ & $\begin{array}{l}7.1 \\
7.0 \\
\text { NS }\end{array}$ & $\begin{array}{l}7.8 \\
7.6 \\
0.1\end{array}$ & $\begin{array}{l}5 \\
4\end{array}$ \\
\hline Surfactant & $\begin{array}{l}\text { Silwet } \\
\text { None } \\
\text { LSD }(P=0.05)\end{array}$ & $\begin{array}{l}0.78 \\
0.76 \\
\text { NS }\end{array}$ & $\begin{array}{l}1.66 \\
1.62 \\
\text { NS }\end{array}$ & $\begin{array}{l}5.7 \\
5.7 \\
\text { NS }\end{array}$ & $\begin{array}{l}7.0 \\
7.0 \\
\text { NS }\end{array}$ & $\begin{array}{l}7.7 \\
7.7 \\
\text { NS }\end{array}$ & $\begin{array}{l}4 \\
5\end{array}$ \\
\hline Fungicide & $\begin{array}{l}\text { Propiconzole } \\
\text { None } \\
\text { LSD }(P=0.05)\end{array}$ & $\begin{array}{c}0.90 \\
0.64 \\
\text { NS }\end{array}$ & $\begin{array}{l}1.57 \\
1.51 \\
\mathrm{NS}\end{array}$ & $\begin{array}{l}5.7 \\
5.7 \\
\text { NS }\end{array}$ & $\begin{array}{l}6.9 \\
7.1 \\
0.14\end{array}$ & $\begin{array}{l}7.6 \\
7.7 \\
\text { NS }\end{array}$ & $\begin{array}{l}4 \\
5\end{array}$ \\
\hline
\end{tabular}

$\mathrm{x}$ On scale of $0=$ no visible symptoms to $7=$ flower cluster dead with lesion extending into stem.

y On scale of 1 to 7 (18). Stage 8 represents young berries.

${ }^{\mathrm{z}}$ Only flowers at stages 4 to 7 at inoculation were included in data analysis.

The increase in Botrytis severity following preinoculation applications of propiconazole possibly is due to injury to stage 5 and 6 blueberry flowers when propiconazole is applied just prior to exposure to high humidity. This injury increases the susceptibility of the flowers to $B$. cinerea infection. Propiconazole has been reported to control mummy berry (Monilinia vaccinii-corymbosi (Reade) Honey) of blueberry (19) when applications are made from leaf bud break through pink bud (early stage 5), and is being considered for registration for use on blueberries.

The relative susceptibility of the cultivars to Botrytis blight varied from study to study. Tifblue and Gulfcoast were more susceptible than Premier and Climax in one study; but in another study, Premier was more susceptible than Tifblue; while in a third study, Climax was more susceptible than Gulfcoast. These differences are probably due to differences in the number of flowers at each developmental stage at the time of inoculation. In the study comparing the four cultivars, all flower stages were included in the data analysis, while only flowers at stage 5 or greater were included in the other two studies. The susceptibility of the two southern highbush cultivars was not dramatically different from that of the three rabbiteye cultivars.

In naturally occurring conditions in the field, where the time of infection may extend over several days when weather conditions are favorable (cool and wet), a combination of a systemic fungicide and a protectant fungicide should give the greatest protective and postinfection control of Botrytis blossom blight on both rabbiteye and southern highbush blueberries. Of the fungicides used in this study, only benomyl and captan are currently registered for use on blueberries. If propiconazole receives registration for mummy berry control (19), strict adherence to label directions con- cerning flower stage at application will be necessary to prevent injury to rabbiteye cultivars that could lead to increased Botrytis blight. The application of gibberellic acid to enhance fruit set should not increase Botrytis severity and may increase fruit set on those flowers with slight injury from Botrytis infection that prevents pollination, much the same as gibberellic acid helps sets berries with slight freeze injury (11). The use of a surfactant with gibberellic acid or fungicide treatments should not affect Botrytis severity. Ripe fruit harvested from plants inoculated during bloom with $B$. cinerea were no more likely to develop Botrytis fruit rot than berries from plants not inoculated. Fungicide application for Botrytis control should begin when blueberry flower buds are at stage 4 and continue until all flowers are past stage 7 .

\section{ACKNOWLEDGMENTS}

I thank Wanda S. Elliott for technical assistance and Charles Pearson, Ciba Crop Protection, Greensboro, NC, for supplying CGA219417 75WP and CGA173506 50WP.

\section{LITERATURE CITED}

1. Austin, M. E. 1994. Rabbiteye blueberries; development, production and marketing. Agscience, Inc., Auburndale, FL.

2. Bertrand, P. 1989. Stem blight and blossom blight - Preventive methods. Pages 59-65 in: Proc. Bienn. Southeastern Blueberry Conf., 4th. University of Georgia, Athens.

3. Bristow, P. R., and Milholland, R. D. 1995. Botrytis blight. Pages 8-9 in: Compendium of Blueberry and Cranberry Diseases. F. L. Caruso and D. C. Ramsdell, eds. American Phytopathological Society, St. Paul, MN.

4. Copes, W., Horton, D., Aims, A., MacDonald, G., Krewer, G., Ferree, M. E., and NeSmith, S. 1997. Commercial blueberry IPM and culture guide. University of Georgia, Athens.

5. Eck, P. 1989. Blueberry Science. Rutgers University, New Brunswick, NJ.

6. Gupton, C. L., Spiers, J. M., and Magee, J. B. 1996. New blueberry cultivars from Mississippi. Pages 19-23 in: Proc. Bienn. Southeast Blueberry Conf., 8th. Univ. Ga. Coop. Ext. Serv.

7. Hendrix, F. F., Jr. 1991. Botrytis blight of strawberries, blueberries and brambles. Georgia Fruit Newsletter, University of Georgia, Athens.

8. Hendrix, F. F., Jr. 1995. Controlling mummyberry and Botrytis. Pages 1-2 in: Proc. Bienn. Southeast Blueberry Conf. Trade Show, 7th. G. Krewer and E. Evert, eds. University of Georgia, Athens.

9. Heye, U. J., Speich, J., Siegle, H., Steinemann, A., Forster, B., Knauf-Beiter, G., Herzog, J., and Hubele, A. 1995. CGA219517; novel broad-spectrum fungicide. Crop Prot. 13:551-559.

10. Krewer, G., Meyer, S., Bertrand, P., Horton, D., Murphy, T., and Austin, M. 1986. Commercial Blueberry Culture. Circ. \#713, University of Georgia, Athens.

11. Krewer, G., and NeSmith, D. S. 1997. Rabbiteye blueberry aid for fruit set in poor pollination situations. Pages 6-8 in: Commercial blueberry IPM and culture guide. W. Copes, D. Horton, A. Aims, G. MacDonald, G Krewer, M. E. Ferree, and S. NeSmith, eds. University of Georgia, Athens.

12. Lyrene, P. M. 1996. Blueberry varieties grown in Florida. Pages 9-18 in: Proc. Bienn. Southeast Blueberry Conf., 8th. Univ. Ga. Coop. Ext. Serv.

13. Milholland, R. D., and Meyer, J. R. 1995. Disease and arthropod pests of blueberries. Bull. 579. N.C. Agric. Res. Serv., Raleigh, NC.

14. Moore, J. N. 1993. The blueberry industry of North America. Acta Hortic. 357:15-27.

15. Pelletier, E. N., and Hilborn, M. T. 1955 Blossom and twig blight of lowbush blueberries. Maine Agric. Exp. Stn. Bull. 529.

16. Rooks, S. D., and Bland, W. T. 1996. New cultivars from North Carolina. Pages 25-29 in: Proc. Bienn. Southeast Blueberry Conf., 8th. Univ. Ga. Coop. Ext. Serv.

17. Smith, B. J., Magee, J. B., and Gupton, C. L. 1996. Susceptibility of rabbiteye blueberry cultivars to postharvest diseases. Plant Dis. 80:215-218.

18. Spiers, J. M. 1978. Effect of stage of bud development on cold injury in rabbiteye blueberry. J. Am. Soc. Hortic. Sci. 103:552-555.

19. Teeter, K. M. 1995. Orbit, a new fungicide for blueberries. Pages 19-20 in: Proc. 1995 Ga. Blueberry Growers Assoc.

20. Varney, E. H., and Stretch, A. W. 1966. Diseases and their control. Pages 236-279 in Blueberry Culture. P. Eck and N. F. Childers, eds. Rutgers University, New Brunswick, NJ. 